\title{
Teoretická východiska politického brandingu: představení modelu voliče orientovaného na hodnotu značky a jeho metodologické ukotvení
}

\author{
The Theoretical Foundations of Political Branding: Introducing the Brand \\ Voter Model and its Methodological Anchoring
}

\section{DANIELA VAŠÁTKOVÁ ${ }^{1}$}

\begin{abstract}
Since the 1960s, voting behaviour in advanced democratic states has undergone substantial changes. From this period, the transformation of social structures, increased education, and the expansion of new technologies in the field of mass media, among other things, are evident. The transformation factors that affect the voter and his choice are sooner or later reflected in new theoretical concepts describing electoral behaviour, whether it was the theory of party identification, voter choice based on issues or rational choice. So far, however, none of the theories have adequately reflected the effect of consumer-style thinking on electoral behaviour. A new trend in political marketing - political branding - aims to correct precisely this deficiency. Due to the fact that the relevant research in the field of political branding and its impact on the voting behaviour of individuals is still in its infancy, we are faced with a lack of robust theoretical foundations. The text thus aims to clarify this situation by gathering and analysing existing branding concepts, pointing to their strengths and weaknesses. Also, it contributes to the theoretical discussion by linking research on political branding to existing theories of voting behaviour, asking whether the related branding concepts are able to explain the voting behaviour of voters as well as whether they are open to further amendments and modifications.
\end{abstract}

Keywords: Voting Behaviour; Political Marketing; Political Branding; Theories of Voting Behaviour; Political Brand

\footnotetext{
${ }^{1}$ Interní doktorandka, Katedra politologie a evropských studií, Univerzita Palackého, Olomouc / Ph.D. candidate, Department of Political Science and European Studies, Palacký University, Olomouc, Czech Republic. Email: daniela.vasatkova@gmail.com.
} 


\section{1. Úvod}

Původní definice Americké marketingové agentury (dále AMA) ze 60. let 20. století definovala značku jako „jméno, termín, označení, symbol, či design nebo kombinace těchto pojmů sloužící $\mathrm{k}$ identifikaci výrobků a služeb jednoho či více prodejců a k jejich odlišení v konkurenci trhu“ (Keller 2007: 33). Avšak v současnosti je již všeobecně přijímaným faktem, že lze koncept značky spojit nejen s fyzickým zbožím, nehmotnými službami či prodejnami, ale také s lidmi, organizacemi, místy a nápady. Značka představuje rovněž několikaúrovňový konstrukt, který lze chápat jako soubor funkčních emočních hodnot, reprezentující dynamický vztah vztahu mezi činy organizace a jejich vnímání zákazníky (de Chernatony 2009: 11). ${ }^{2}$ Branding odlišuje jinak podobné produkty zdůrazňováním jak odlišností, které jsou racionální a hmotné (spojené spíše s výkonem daného produktu), tak těch nehmotných a emočních (spojených s tím, co značka znamená). Fungující branding musí sloučit obě dimenze a brát v potaz srdce i rozum (Downer 2013: 5). Pokud se $\mathrm{k}$ němu přstupuje efektivně, napomáhá konzumentům ve vytváření si pozitivních asociací o značce i jejích produktech. Politický branding pak lze definovat jako cílevědomý proces či soubor aktivit, jejichž úkolem je poskytovat marketingovou efektivitu při budování loajality voličů a navodit u nich stranou požadované pozitivní asociace s ní. ${ }^{3}$

Vzrůstající význam brandingu v politice se nesetkává s odpovídajícím zájmem politologů. Douglas Holt ve svém krátkém komentáři vystihl současný vztah brandingu a politických věd: „Dnes je branding ústřední činností kapitalismu, takže by měl být součástí jakýchkoliv snah a pokusů porozumět současné společnosti a politice. Avšak mimo prostory manažerských škol je branding i přes svůj společenský př́nos jen zřídka objektem empirického výzkumu a teoretického rozvoje.“ (Holt 2006: 300) Literatura, která se zabývá výlučně rolí značek $\mathrm{v}$ politice, trpí značnou nesystematičností a většinou je pouhou podmnožinou prací o politickém marketingu. Její autoři se ale vesměs shodují v jednom: Zatímco před dvaceti lety se dal za nový způsob, jak porozumět moderní politice,

\footnotetext{
2 Kupř́kladu funkčními hodnotami Labour Party ve Spojeném království v 90. letech byly otevřenost, modernita a redistribuční sociální politika. Po emocionální stránce ale strana u voličů vzbuzovala obavy z návratu silného postavení odborů, které v 70. letech paralyzovaly labouristickou vládu. Při změnách atributů značky strany pod vedením Tonyho Blaira tak byly analyzovány obě složky s cílem získat voliče z řad střední tř́dy (de Chernatony a White 2002: 4).

$3 \mathrm{~V}$ př́padě, kdy se politické straně nedaří budovat požadovaný obraz značky $\mathrm{v}$ očích voličů, se může stát, že image značky bude až př́liš zatížen negativními asociacemi voličů. To byl př́klad Konz̧ervativní strany v roce 2006 ve Velké Británii. V rámci průzkumu YouGov se výzkumníci dotazovali dvou skupin voličů na jejich postoje $\mathrm{k}$ návrhům imigrační politiky konzervativců. Ti, kteří nevěděli, že popsané politiky jsou součástí programu této strany, je schvalovali v míře o 12 bodů vyšší než v případě, kdy věděli, že se jedná o její strategii (Smith 2009: 210). V tomto př́padě tak značka hrála $\mathrm{v}$ neprospěch stranických politik.
} 
považovat politický marketing, dnes je tímto jedinečným nástrojem politický branding (Downer 2013: 9).

Koncept politické značky je značně inkluzivní a dokáže zahrnout poznatky cenné nejen pro oblast politických věd, ale i věd ekonomických, psychologických a dalších. $\mathrm{Na}$ základě toho dochází $\mathrm{k}$ artikulaci teorií, které se svojí interdisciplinaritou mnohdy zachází do bodu, kdy tvrdí mnoho a zároveň nic. Martin Kornberger (2006: 13) tvrdí, že „značky jsou fakta hledající svou teorii.“ Reaguje tak na skutečnost, kdy jsou značky intenzivně představovány a jsou v našem povědomí, ale doposud zde chybí jejich řádný výzkum a následné jasně uchopitelné teorie. Nacházíme se tak v situaci, kdy narůstají iniciativy politických subjektů vytvářet vlastní stranickou nebo osobnostní značku, na straně druhé je však politologický výzkum v oblasti brandingu stále ještě ve svých počátcích.

Obzvláště to platí $\mathrm{v}$ př́ipadě budování a řízení značek $\mathrm{v}$ politice s důrazem na vztah k volebnímu chování jednotlivců. v zahraniční odborné literatư̌e lze nalézt řadu prací, které přichází s novými, případně lehce modifikovanými způsoby měření image či hodnoty politických značek (stran, politiků apod.), ale výsledná stanoviska již nedokáží propojit s klasickými politologickými teoriemi. Velmi často jsou odborné články redukovány na představení situace $\mathrm{v}$ oblasti politického brandingu v konkrétní zemi či u specifické politické strany. Není proto divu, že je disciplína politického brandingu (a v širší perspektivě i politického marketingu) předmětem diskuzí o tom, zda jsou její výzkumné postupy dostatečně sofistikované na to, abychom je mohli řadit mezi ty z klasické politologie. Předkládaná kritická přehledová studie se tak snaží tuto situaci vyjasnit a shromáždit pouze takové brandingové koncepty, jež se dotýkají efektu značek na volební chování, a následně přispět do teoretické diskuze jejich systemizací. Její ambicí tak není vyčerpávající přehled všech doposud publikovaných studií, ale pouze těch, jejichž předmětem výzkumu je volič a jeho ovlivnitelnost značkou při rozhodování o volební podpoře dané politické strany. Díky této studii by tak měl čtenár získat ucelený přehled teoretických př́stupů i metodologických postupů výzkumu možných dopadů brandingu na společnost, konkrétně na její volební chování. Předkládaný text tak poukáže na oblast výzkumu, která je ukázkou spojení politologie a brandingu a popírá tak kritiku deklarující politický branding jakožto pouhou deskripci marketingových technik užívaných politickými stranami k budování značek.

Předkládaný text je strukturován následovně. Druhá sekce má čtenáři nabídnout představu o současném postavení politického brandingu v politologii, respektive politickém marketingu. Ukazuji zde také, odkud politický branding primárně přejímá základní terminologii a teoretické rámce. Třetí sekce podává stručný nástin ústředních teorií volebního chování, které dnes mohou narážet na své explanatorní limity a které ve svém základu souvisí i s rozmachem politického marketingu. Ve čtvrté sekci je představen zcela nový koncept voliče orientovaného na hodnotu politické značky, který má potenciál v současnosti 
pomoci politologům vysvětlit změny ve volebním chování. Konkrétní konceptuální rámce, které z něj vychází, jsou diskutovány v páté sekci.

\section{Politický branding jakožto sub-disciplína politického marketingu}

V dostupné literatuře lze nalézt dva základní př́istupy ke studiu a analýze značek. Zatímco jeden se soustředí na řízení značky (tzv. brand management), druhý se na danou oblast dívá perspektivou konzumenta (Keller 2002: 153). v prvním př́padě slouží branding stranám k porozumění jejich potenciálním voličům, od jejichž přízně se skrze volební podporu odvíjí síla jejich postavení ve stranickém systému. Zejména pak strany tradiční, které v posledních letech čelí konkurenci v podobě populistických hnutí velmi efektivně využívajících nástrojů politického marketingu (v českém prostředí efektivně využívá marketingové nástroje zejména hnutí $\mathrm{ANO}^{4}$ ), upírají čím dál častěji svưj zájem k budování a spravování politické značky. ${ }^{5}$ Politické strany skrze systematické budování a řízení značky, tedy podstatnou část politického brandingu, mohou ovlivnit, jaký typ asociací a emocí u lidí navodí.

$\mathrm{V}$ případě druhého př́stupu může politický branding pomoci politologům pochopit faktory ovlivňující volební chování a vedoucí voliče vstříc konkrétní volbě. Smith a French již v roce 2009 argumentovali tím, že způsob, jakým voliči získávají znalost a následně užívají politické značky, je důležitým prvkem ve volebním rozhodování (Smith a French 2009). V témže roce publikovali Peng a Hackley studii, ve které popisují charakteristiky voličského chování napodobující chování spotřebitelů, zejména když dojde na nahrazení informací o straně pouze subjektivním vnímáním kandidáta či image strany (Peng a Hackley 2009).

Přestože se oba prístupy liší svým předmětem zájmu (management strany vs. orientace na voliče), oba $\mathrm{v}$ teoretické rovině tvoří subdisciplínu politického marketingu a přebírají z něj nejen pojmosloví, ale i základní teoretické koncepty. Zejména manažerský př́istup jakožto součást konceptu politické značky vychází z ekonomie a marketingu, který učí politické strany a jejich stratégy budovat

\footnotetext{
${ }^{4}$ Zajímavé srovnání marketingu předních českých politických stran, ze kterého je jasná dominance hnutí ANO uveřejnil web Hlidacipes.org (2017).

${ }^{5}$ Jednou z tradičních stran, která se v posledních letech snaží definovat identitu a pozici své značky, je Česká strana sociálně demokratická (ČSSD). Programové priority, ideologické pozadí i výběr lídrů jsou v současné době ze strany představitelů strany předkládány jakožto diskuze nad konečnou podobou značky ČSSD. V souvislosti s nadcházejícími volbami do Poslanecké sněmovny bývalý místopredseda strany Michal Hašek uvedl, že „volby budou bojem o značku strany. "V praktické rovině však procesy v ČSSD nejeví známky systematického budování a rrízení značky. Straně se nedaří navozovat u voličů požadované pozitivní asociace; součástí značky ČSSD se naopak staly okolnosti, které strana nedokázala kontrolovat (korupční skandály, vnitřní nejednotnost atp.) (Lidovky.cz 2017).
} 
cennou politickou značku, od níž se očekává výjimečnost. Politický branding obdobně jako politický marketing pracuje s premisou, která ve své základní a zjednodušené podobě definuje politické strany jako organizace, prostřednictvím nichž politici usilují o směnu idejí a slibů za volební podporu. v rámci analogie s komerčním marketingem lze na volby pohlížet jako na moment prodeje - bod, ve kterém voliči využijí svých znalostí o kandidátovi a straně a učiní volbu (Fawcett a Marsh 2011: 519). Tento výběr v době voleb tak může být srovnatelný $\mathrm{s}$ tím, který činí konzument při pořizování zboží či služeb.

Zde je však nutné varovat před bezbřehým přejímáním zmiňovaných konceptů z komerční sféry do něčeho tak specifického jako je politické prostředí. Naprríklad Lock a Harris argumentují pestrostí produktové nabídky politických stran, kterou nelze srovnat s obchodními „protějšky“. Nadto je při volbách člověk nucen zvolit danou stranu včetně celé její programové nabídky, zatímco v soukromém sektoru se takto značky nechovají. Zákazník není nucen zakoupit celou produktovou řadu, ale jen ty výrobky, které si vybere. i samotný produkt, který volič „zakoupi“ výměnou za svůj hlas, může být do doby svého dodání vlivem okolních podmínek (nap̌r. kompromisu v rámci vládní koalice) pozměněn (Harris a Lock 1996: 14-15). Smith a French (2009: 210) dále varují před tendencí brandingu zjednodušovat a redukovat politickou agendu na pouhé symboly a hesla. Na druhou stranu právě silný důraz na symboliku, rétoriku a přidanou hodnotu jsou znaky, které výrazně odlišují politický marketing od komerčního, protože politické apely se mnohem více spoléhají na symbolické konotace a podtext. Velmi často není pozornost věnována čistě konkrétním politickým návrhům čili části nabízeného produktu (který se může proměnit nebo dokonce nebýt vůbec dodán), ale přidané symbolické hodnotě v podobě konkrétní rétoriky nebo obrazů. Podle Henneberga (2002) jsou si politologové vědomi rozdílů v napojení na jedné straně spotřebitele a na druhé straně voliče na značku, prričemž druhý zmiňovaný se více spoléhá na hlubší symboly a sdílené hodnoty, zatímco spotřebitel se více zajímá o co nejkonkrétnější specifikaci produktů.

Většina autorů se tak shoduje, že analogie mezi konzumentem a voličem, př́padně politickou stranou a producentem, je v rámci politologického výzkumu aplikovatelná a ospravedlnitelná, ale za předpokladu zvážení všech výše zmíněných rozdílů. Přesto je mnohem přesnější vnímání politických stran a jejich představitelů skrze marketing služeb, ${ }^{6}$ nebot' politické nabídky stejně jako služby v komerční oblasti jsou založeny na principu budoucího dodání. Voliči tak nejsou považováni za konzumenty, ale potenciální klienty, kteří ve značkami přesycené společnosti vnímají politické strany shodně se značkami ze sektoru služeb a jsou rovněž schopni přenést a využít své znalosti komerčních značek do politické sféry

\footnotetext{
${ }^{6}$ Vedle marketingu služeb se $\mathrm{v}$ současné době věnuje čím dál více publikací budování značky v sektoru neziskových organizací, které se politickým stranám v řadě ohledech podobají (Holland 2006).
} 
(Smith 2009: 210). Například předvolební proklamace slibující provedení důsledných reforem mohou být naplněny až téměr u konce vládního mandátu. To, co mírní nejistotu voličů, zda je daná strana schopna svého závazku opravdu dostát, je stávající status značky. Marketing služeb, který je silně svázán s budováním důvěry a závazků, tak představuje možný vůdčí koncept pro management politického marketingu (Henneberg 2006: 226). Ve stejném duchu hovoří taktéž Bruce Newman, který tvrdí, že politické osobnosti nelze obchodovat jakožto obchodní komodity, nýbrž jako poskytovatele služeb (Newman 1993).

Vzhledem k faktu, že relevantní výzkum voblasti politického brandingu a jeho vlivu na volební chování jedinců je teprve ve svých počátcích, lze v něm pozorovat nedostatek zřetelných teoretických východisek. Svou roli může hrát i nedůvěra některých politologů ${ }^{7} \mathrm{k}$ možnosti aplikace brandingových postupů v politických vědách. Následující sekce věnovaná teoriím volebního chování spadajícím do klasické politologie ovšem poukazuje na kontext, díky němuž je možné vhodně etablovat subdisciplínu politického brandingu v rámci politologie

\section{Proměny volebního chování aneb jsou stávající teorie dostačující?}

Americký politolog John Coleman považoval za klíčovou otázku politiky stran jejich schopnost mobilizovat a integrovat masovou veřejnost do demokratického procesu (Coleman 1996). v tomto ohledu bylo vždy důležitým měrítkem napojení veřejnosti na politické strany, s čímž souvisí známý a hojně užívaný koncept stranické identifikace, se kterým v roce 1960 přišli Argus Campbell a kol., a který navazoval na předchozí behaviouralistickou koncepci (Campbell et al. 1960) Zatímco míra stranické identifikace v době stranických kampani ${ }^{8}$ byla vysoká, od konce 60 . let dochází k jejímu výraznému poklesu. Naneštěstí pro politické strany se nejednalo o jedinou zásadní změnu v chování voličů, na kterou byly nuceny reagovat

(Lees-Marshment 2001). Trend odcizení doposud stabilního elektorátu od politických stran byl způsoben kombinací individuálních i systémových faktorů, které transformovaly stávající vyspělé průmyslové demokracie (Dalton a Wattenberg 2000: 22). Proběhla postupná tranzice od kolektivní ideologické politiky poválečného období směrem k nové politické kultuře, jež se dala označit za pragmatičtější a volatilní (Blumler a Kavanagh 1999: 211-213). Občané nadále nenásledovali dlouhodobé a pevné stranické loajality, ale směrovali svou pozornost ke specifičtějším otázkám, z nichž většina nenašla oporu ve stranických

\footnotetext{
7 Viz např. Scammel (1999).

8 Období stranických kampaní je období do první poloviny 20. století. Kampaně byly organizovány čistě za pomocí vlastních stranických sil bez najímání externích odborníků.
} 
programech (Adolphsen 2009: 10). Díky masovému rozšúření vzdělání, zvláště vysokoškolského, stály politické strany tvárí v tvář vzdělanějšímu elektorátu s vyšší mírou politických schopností a znalostí. Vyšší úroveň vzdělání znamenala kritičtěji smýšlející voliče, méně svázané s danou politickou stranou (Lees-Marshment 2001: 18). Co je taktéž podstatné je skutečnost, že politické znalosti a informace už nezískávali voliči jako generace před nimi skrze stranické tiskoviny. Se 60. léty 20. století je spojen technologický a mediální rozmach a nástup plošně působících masmédií, konkrétně televize. Expanze masových médií a jejich narůstající vliv $\mathrm{v}$ politickém procesu vedly $\mathrm{k}$ vytvoření médii utvářené veřejné sféry ovlivňující mínění voličù (Blumler a Kavanagh 1999: 211). Společně s proliferací zájmových skupin nahrazovala masová média politické strany jako zdroje politických informací a snižovala u nich jejich stranicky zabarvený obsah.

V rámci sociální struktury narostla ekonomická a geografická mobilita, mající za následek méně kontrolovanou sociální organizaci a interakci. Podle německého sociologa Ulricha Becka, který reflektoval široké sociální změny např́íc společnostmi vyspělých demokracií, započala $\mathrm{v}$ dané periodě transformace z prosté „první modernity“ k reflexivní „druhé modernitěc. Zatímco první byla založena na společenství národního státu a dané kolektivní identitě jako třída, rodina či etnicita, druhá modernita se vyznačuje individualizací, globalizací a nejistotou (Beck 1992). Byla to právě nejistota, která donutila politické strany změnit nejen jejich vnitřní organizační strukturu, ale v závislosti na to taktéž charakter politické komunikace. Druhá modernita znamenala nástup éry profesionálního politického marketingu a s ním spojeného řízení stran jakožto značek. Pokud volič již nadále neshledával sociální a ideologické ukotvení jako hlavní důvod své volby, stala se pro politické strany změna interní struktury i celkového chování nevyhnutelná. v 50. letech německý politolog Otto Kirchheimer pozoroval, že voliči v západním Německu jsou čím dál flexibilnější ve svých volebních preferencích a preferuji umírněné a výrazněji ideologicky nevyhraněné strany, které sám nazval „catch-all parties“ (všezahrnující strany) (Kirchheimer 1966). Potencionální voliči již nejsou oslovováni v doposud jasně vyhraněném prostoru a dosavadní přesvědčovací techniky tak nemohou obstát. Stejně neodvratná byla transformace vnitřních struktur stran. Ty přistoupily $\mathrm{k}$ redukci ideologické zátěže, posilování pozic vedoucích skupin, oslabování role individuálních členů a zajištění prrístupu $\mathrm{k}$ řadě zájmových skupin $\mathrm{z}$ finančních i volebních důvodů (Krouwel 2003: 26-27). Při konstruování konceptu všezahrnující strany autor částečně vycházel $z$ teorie veřejné volby, jež pojímala stranu jako politický podnik soutěžící s ostatními politickými subjekty o politickou moc na politickém trhu. Aby si strany zajistily volební vítězství, musely „vstoupit do povědomí miliónů voličů jako povědomý objekt plnící v politice roli analogickou té, kterou zastávají hlavní značky v marketingu všeobecně potřebných a vysoce standardizovaných výrobků masové spotřeby“ (Kirchheimer 1966: 192) 
Tendence politických stran zastávat centristické pozice a zajistit si tak největší šance na politickém trhu, kde se voliči chovají racionálně a ekonomicky, popsal z ekonomického úhlu pohledu v roce 1957 Anthony Downs. Tento trh, na kterém spolu o zákazníka/voliče soutěží celá řada subjektů, které jsou si velmi podobné (zejména co se programové nabídky týče) vyžaduje, aby strany přejímaly nové strategie $\mathrm{v}$ politické komunikaci, včetně budování a rozvoje značky. Downsovo tvrzení se však stahuje pouze na systém dvou stran, který předpokládá specifické rozložení elektorátu - nejvíce hlasů se shlukuje v politickém středu. Naopak v prrípadě vícestranických systémů, kde je rovnoměrnější rozložení populace od extrémní levice po extrémní pravici, vyzdvihuje Downs podstatu ideologického pozadí každé strany, které jí pomáhá se odlišit od konkurentů. v prrípadě, že by se strana rozhodla opustit svou ideologii a pozičně se posunout na pravo-levé škále, pravděpodobně hlasy navíc nezíská, naopak riskuje ztrátu podpory svých tradičních voličů (Downs 1957). Je nutné si uvědomit, že Downs sice zapojil do svých koncepcí logiku i jazyk ekonomické a marketingové sféry (Eghbalian a Hennenberg 2002: 67), ale ani on neopomíjí důležitou roli ideologií. Avšak jeho práce je datována do 50. let dvacátého století, kdy postavení ideologie jakožto faktoru ovlivňujícího volební chování bylo silné. Naopak v současné době se někteří autoři přiklání $\mathrm{k}$ tezím o upozadění role ideologií (Davis 2010; Costa a Corte-Real 2013), což se ostatně stalo jednou z prričin rozmachu politického marketingu a v konečném důsledku i jeho sub-disciplíny politického brandingu. Zatímco před několika desítkami let to byla mimo jiné právě ideologie, která sloužila k odlišení stran na trhu, dnes se může tuto funkci zastat hodnota politické značky.

Obdobně je nutné hledat i na straně voličů nové proměnné ovlivňující jejich volební rozhodování, které doplňují či dokonce do jisté míry nahrazují ty stávající. Přestože pro politology jsou stále významnými nástroji pochopení volebního chování stávající klasické sociologické, ekonomické či sociopsychologické teorie (včetně svých předpokládaných revizî), politické značky a politický branding jako takový nám poskytují alternativní nástroj pro pochopení a vysvětlení současného volebního chování a vyplňují tak mezery, které klasické teorie nezvládají pokrýt (Nielsen a Larsen 2013: 154) - a to i proto, že jsou v jádru založeny na společném konsensu, který tvrdí, že většina voličů má stabilní či relativně stabilní předpoklady $\mathrm{k}$ volbě jedné nebo druhé strany, přičemž tyto předpoklady jsou považovány za neměnné a vliv na ně má mít politická zkušenost každého jednotlivce. $v$ neposlední řadě se pak klasické teorie shodují na tom, že politika je pro většinu voličů po větší část jejich života zcela vzdálená jejich každodenním starostem. Tyto teorie tak dostatečně nepracují s důsledky nevědomostí a neznalostí voličů, stejně jako (a zejména) se způsobem, jakým voliči získávají a zpracovávají informace a utvárí si emoce vůči politickým stranám (Henneberg 2002) Právě v tomto ohledu může být marketingový, respektive brandingový přístup k chápání vlivů na volební chování pro politologii přínosem. v dalších 
dvou sekcích se proto konkrétně zaměŕím na vysvětlující potenciál modelu voliče orientovaného na hodnotu politické značky a zároveň způsoby, jak související vlivy měrit.

\section{Volič orientovaný na hodnotu politické značky}

Volič, obdobně jako konzument v komerční sféře, očekává od politické strany, tedy poskytovatele služeb, dvě základní vlastnosti: kompetentnost a spolehlivost. Značka politické strany jako subjektu poskytujícího určité služby nestojí a nepadá s jedním protagonistou - lídrem; její budování a řízení se naopak musí vždy soustředit na veškeré atributy, respektive identifikátory brandu. Přestože lídři politických stran jsou nejviditelnějšími protagonisty značky, nejsou jejími trvalými součástmi. $\mathrm{v}$ ideálním př́ípadě musí mít volič/spotřebitel jistotu, že $\mathrm{v}$ př́padě nahrazení předsedy strany, př́padně voleného zástupce strany v exekutivní funkci, nedojde k oslabení kompetentnosti či spolehlivosti značky. v praxi je ale patrný velmi silný vliv značky lídra na celkovou značku strany. Dobré značky vytváří s konzumentem emocionální spojení, které mu umožňuje zformování tzv. rozhodovací zkratky. Pro mnoho voličů je totiž získávání politických informací př́liš nákladné, což je dále umocněno potřebou odlišit si návrhy jednotlivých stran. Připočtěme $\mathrm{k}$ tomu značně fragmentované mediální prostředí, v němž o pozornost soutěží zprávy apolitického i politického charakteru. Vzhledem $\mathrm{k}$ těmto nákladům i nutností projít všemi komunikačními uzly může voličům ušetřit drahocenný čas věnovaný vyhledávání relevantních sdělení právě rozhodovací-informační zkratka, která jim napomáhá ve volebním rozhodování. (Smith 2009: 212; Bartle a Griffiths 2002). Studie naznačují, že voliči spoléhají na kognitivní zkratky, jež jsou rozvinuty na základě bezprostředního vnímání kandidáta a strany a mohou fungovat jako náhražka za detailní informace (Needham 2006: 181). Paralelně $\mathrm{k}$ tomu vede vytváření emocionálního užitku u voličů k pocitu sounáležitosti a solidarity se skupinou podobně smýšlejících občanů ve smyslu sdílení stejných hodnot a pocitu silné identifikace s daným seskupením (Schneider 2004: 52). Vedle toho redukuje znalost značky a jejích předních atributů potřebu detailní znalosti o produktu (volič např́klad nemusí mít povědomí o celé programové nabídce strany, pokud si vybaví základní atributy) (Needham 2006: 179).

Pro model voliče orientovaného na politickou značku (v angličtině brand voter model) je zásadní teoretický koncept tzv. lidské asociační paměti (Human Associative Memory, HAM), který kombinuje poznatky z marketingu a psychologie a vychází z teorie učení. HAM se skládá ze sítě uzlů, které jsou její základní složkou a vzájemně se aktivují v rámci relevantního kontextu - viz schéma č. 1 (Teichert a Schontag 2010: 370). Perspektivou vnímání značek je informační uzel v paměti konzumenta složen z asociací ke značce, jež vznikají pokaždé, kdy se jedinec 
se značkou setká - v jakékoliv její podobě, nejčastěji skrze vizuální stimuly. ${ }^{9}$ Nicméně většina stř̌etnutí se značkou je multimodální, aktivující různé smysly a tím pádem i odlišné části mozku. Uzly, které se v těchto částech nacházejí, jsou propojeny a vytvárí tak ucelenou pamět', čímž je umožněno rozpoznání značky a vyvolání povědomí o jejích atributech. Koncept HAM je vystavěn na principu šírení aktivace, který odkazuje na aktivaci uzlů ze strany tzv. zdrojových uzlů. Silnější propojení jednotlivých uzlů zvyšuje pravděpodobnost šíření aktivace mezi nimi. Zmíněná propojení daných uzlů můžou být posílena a upravována pomocí procesu učení.

\section{Schéma č. 1: Př́iklad znázornění asociační sítě}

\begin{tabular}{cccccccccc}
\hline & & $\mathbf{A}$ & $\mathbf{B}$ & $\mathbf{C}$ & $\mathbf{D}$ & $\mathbf{E}$ & $\mathbf{F}$ & $\mathbf{G}$ \\
\hline $\mathbf{A}$ & 0 & 2 & 0 & 1 & 3 & 3 & 0 \\
$\mathbf{B}$ & 2 & 0 & 3 & 0 & 0 & 0 & 0 \\
$\mathbf{C}$ & 0 & 3 & 0 & 1 & 1 & 0 & 2 \\
$\mathbf{D}$ & 1 & 0 & 1 & 0 & 0 & 0 & 0 \\
$\mathbf{E}$ & 3 & 0 & 1 & 0 & 0 & 1 & 0 \\
$\mathbf{F}$ & $\mathbf{F}$ & 3 & 0 & 0 & 0 & 1 & 0 & 0 \\
$\mathbf{G}$ & & 0 & 0 & 2 & 0 & 0 & 0 & 0 \\
\hline
\end{tabular}

Zdroj: Teichert a Schontag (2010).

Poznámka: Velikost uzlů (kružnice označena písmeny, která odlišují jeden uzel od druhého) je ovlivněna počtem př́ípadů, kdy byla konkrétní asociace zmíněna a znázorňuje tak sílu asociace. Šiŕka př́mek mezi uzly představuje počet př́ípadů, kdy byly zároveň zmíněny dva vzájemně propojené koncepty. Číslo zobrazené vedle přímek tak může být interpretováno jako síla kontextuální propojenosti dvou uzlů. Tato síla pro každou dvojici uzlů je znázorněna $v$ tabulce vpravo. Např́klad uzly $B$ a $C$ jsou silně propojeny v porovnání s uzly $\mathrm{G}$ a $\mathrm{B}$, kde je propojenost dokonce nulová.

Model voliče orientovaného na politickou značku je tak založen na předpokladu zpracování informací, kdy jsou voliči zaměřeni na poznávání stran v momentě konfrontace s politickými zprávami. Poznávání a učení není však nijak motivováno. Volič sbírá kousky informací, jak v jeho každodenním životě přijdou, a následně tyto fragmenty znalostí uchovává ve své paměti. V momentě, kdy je v paměti aktivována politická značka, kousky asociací uchované v dlouhodobé paměti jsou náhodně přesměrovány do paměti krátkodobé, kde jsou mezitím ve

\footnotetext{
${ }^{9} \mathrm{~V}$ tomto ohledu je vhodné zmínit důležitost loga jakožto vizuálního atributu, který také výrazně ovlivňuje vnímání značky strany voliči.
} 
větší míře přítomny i nejaktuálnější a nejdůležitější asociace. Když poté volič stojí před rozhodnutím, komu dát svůj hlas, využívá daných asociací jakožto intuitivního nástroje, který funguje jako předpoklad ovlivňující voličovo mínění. Proces řídící celý tento mechanismus je označován jako „hodnota politické značky“, která v konečném důsledku rozhoduje o tom, jak žádoucí či nikoliv je konkrétní politická nabídka pro voliče v momentě, kdy si s ní spojí jméno značky (Nielsen a Larsen 2014). Hodnota politické značky v sobě spojuje dvě z celkem tř́ nejdůležitějších oblastí užívání značky voličem (viz schéma č. 2).

\section{Schéma č. 2: Tř̌i důležité oblasti užívání značky dle Tiffany Winchester}
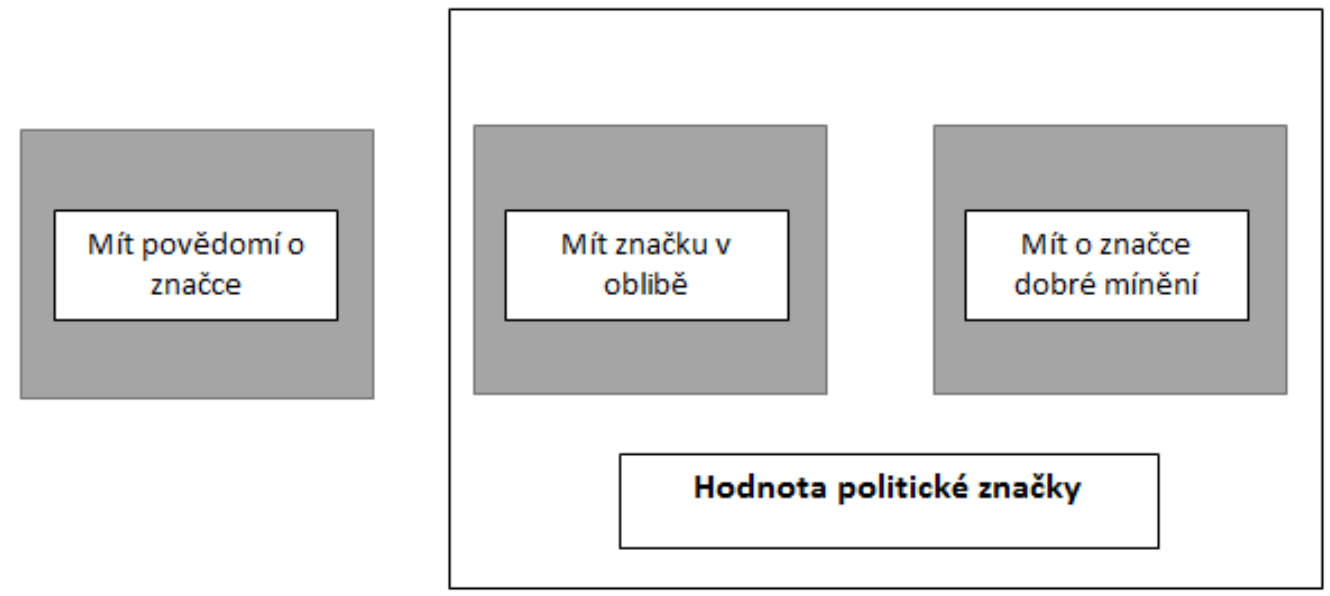

Zdroj: Winchester et al. (2016). Upraveno autorkou.

Pro voliče orientovaného na politickou značku je zcela zásadní jejich znalost, která je základem pro jejich vnímání i možnou diferenciaci. Tato znalost se nejdříve utváři na úrovni povědomí o značce, jež sestává z jejího vybavení a rozpoznání. „Rozpoznání značky se vztahuje ke schopnosti spotřebitele potvrdit dřívější seznámení se značkou, pokud k tomu dostane impuls. Jinými slovy, rozpoznání značky vyžaduje, aby spotřebitelé mohli správně rozlišit značku, jako něco, co již dř́ve viděli či o tom slyšeli““ (Keller 2007: 98). Jedině povědomí o značce může následně zvýšit pravděpodobnost, že se tato stane součástí zvažovaného souboru, který tvoří skupina značek, o jejichž koupi spotřebitel uvažuje. Podle nejnovějších výzkumů z oblasti komerčního marketingu jsou konzumenti jen zř́́dka věrni pouze jednomu brandu a často tak mají soubor značek, které přicházejí v úvahu ke koupi. Podobný jev můžeme pozorovat u voličů, kteři ve značné části př́padů nejsou pevně rozhodnuti, kterou stranu volit nebo se jejich rozhodnutí mění v dalších volbách. Nerozhodnutý a volatilní elektorát hraje ve volbách stále významnější roli (Dostál 2010) a proto ,je třeba zajistit, aby značka byla ve zvažovaném souboru a aby ostatní značky měly menší 
pravděpodobnost, že si na ně spotřebitel vzpomene, nebo je bude zvažovat. Psychologický výzkum částečného seznamu účinků - podnětů ukázal, že vzpomínka na některé informace může inhibovat vzpomínky na jiné informace“ (Keller 2007: 99). v kontextu politického marketingu to znamená, že pokud se člověk rozhodne jít $\mathrm{k}$ volbám, do zvažované množiny stran $\mathrm{k}$ volbě budou spadat právě ty, o nichž má určité, byt' minimální, povědomí - a to i v případě, že nemá $\mathrm{k}$ dané politické značce žádné asociace. ${ }^{10}$ „Jeden ze základních modelů změny postojů a přesvědčování, model rozpracování-pravděpodobnost, vychází z názoru, že spotřebitelé mohou nakupovat na základě faktorů povědomí o značce, pokud není volba náročná. Nízká náročnost vzniká, pokud spotřebitelé nemají motivaci k nákupu nebo neumějí nakupovat (např. když spotřebitelé neví nic o značkách v dané kategorii)" (Keller 2007: 99). Obdobné závěry indikují i výsledky průzkumu CVVM SOÚ AV ČR mezi českými voliči z listopadu roku 2014, kam byly zahrnuty i otázky testující znalost log politických stran. ${ }^{11}$ Nejenže znalost log můžeme vnímat jakožto druh znalosti politické (Kudrnáč 2015), ale rovněž dle autora tato souvisí i s volebním chováním. Data kupříkladu naznačují, že ti respondenti, kteří znají více log, mají vyšší šanci jít k volbám a volit nelevicovou stranu (ibid: 41). Jiné studie z komerční oblasti prokázaly korelaci mezi užíváním značky a její subjektivní dominantní pozicí v mysli spotřebitele. Uživatelé značky byli lépe obeznámeni s danou značkou než lidé, kteří ji nevyužívali. Povědomí o značce je tak důležitým determinantem volby (Nedungadi a Hutchinson 1985).

\section{Měření vlivu hodnoty značky na voliče - zhodnocení dostupných konceptuálních rámců}

Doposud publikované práce věnující se měření hodnoty politické značky můžeme rozdělit do dvou základních kategorií podle toho, zda je hodnota značky definována pomocí vztahu mezi zákazníkem a značkou (spotřebitelsky orientovaný přístup), nebo pomocí aktivit a procesů, které se dějí vlastníkovi značky (přístup orientovaný na producenta - manažerský př́stup). v prvním př́padě se výzkum zaměruje na procesy, které vycházejí z politického brandingu a ovlivňují chování jedinců (volební i nevolebnî), v př́padě druhém je teoretický výzkum výrazněji upozaděn ve prospěch praktických rad pro politické strany a kandidáty, jak nejefektivněji přistupovat k budování a řízení své značky.

\footnotetext{
${ }^{10}$ Je zcela logické, že pokud jedinci není znám název strany, logo nebo další možný atribut značky, je zde vysoká pravděpodobnost, že danou stranu volit nebude, nebot' si nemůže být jistý její identitou či dokonce kandidaturou.

${ }^{11}$ Logo řadíme mezi základní identifikátory značky, které slouží k jejich identifikaci a diferenciaci. Mimo to mohou vytvářet co nejvyšší hodnotu značky a zjednodušit tvoření silných, jedinečných a př́żnivých asociací. Keller (2007: 204) definuje několik základních atributů značky, jimiž jsou: jméno, logo, symboly, představitelé, mluvčí, slogany, znělky, balení a nápisy.
} 
Následně lze práce dělit na základě předmětu jejich zájmu. Jak je zmíněno $\mathrm{v}$ předchozích sekcích, značka $\mathrm{v}$ politice není tvořena pouze politickou stranou, ale její součástí jsou i lídři a ostatní kandidáti jakožto reprezentanti strany. Protože se jedná o významnou součást celkového vnímání značky a při studiu hodnoty značky kandidáta měříme její rozpoznatelnost pomocí jiných atributů než u stran, jsou jí věnovány samostatné výzkumné práce. Tabulka č. 1 shrnuje prŕstupy (a autory) věnující se voličsky orientovanému zkoumání se zaměřením jak na hodnotu značky kandidáta, tak na hodnotu značky strany, a pracující s konceptem lidské asociační paměti, jež je pro model voliče orientovaného na politickou značku zásadní.

\section{Tabulka 1: Přístupy orientované na vnímání hodnoty značky voličem a pracující} s HAM

\begin{tabular}{|c|l|}
\hline a. $\quad \begin{array}{l}\text { French a Smith } 2010 \\
\text { McDonald, Sherlock a Hogan 2014 }\end{array}$ & Brand Concept Maps \\
\hline b. Aleksiejevas 2012 & Multidimenzionální pŕístup \\
\hline c. Pich a Dean 2015 & Kvalitativní projektivní techniky \\
\hline d. Almohammad 2014 & Emotion based political brand equity \\
\hline
\end{tabular}

Zdroj: Sestaveno autorkou.

\section{a. Smith a French; McDonald, Sherlock a Hogan: Brand Concept Maps}

Přelomovou prací v měření hodnoty politické značky je článek Alana Frenche a Garetha Smitha „Measuring political brand equity: a consumer oriented approach“ (French a Smith 2010). Sami autoři ve svém příspěvku nezastírají ambice představit nový zákaznicky orientovaný přístup $\mathrm{k}$ mapování politické značky s důrazem na asociace, konceptuálně vycházející z teorie konzumního učení a metodologicky stavěný na empiricky ověřených postupech měření značek v komerční oblasti. French se Smithem vycházejí z hojně užívaného př́stupu konceptualizujícího čtyři dimenze hodnoty značky vztahující se k osobě zákazníka (jedná se tedy o prípad zákaznicky orientovaného př́istupu). Konkrétně jde o následující dimenze: povědomí o značce, loajalita, vnímaná kvalita a asociace se značkou. Až na jednu výjimku korespondují se známým měrícím nástrojem Jennifer Aaker z roku 1991, původně zaměřeným na komerční produkty a trhy. Sama autorka si byla vědoma univerzálnosti svého nástroje a o několik let později vybídla $\mathrm{k}$ jeho modifikaci, která by brala $\mathrm{v}$ potaz odlišný kontext a cíl měření. French a Smith tak činí, přičemž věnují primární pozornost asociacím se značkou, které nebyly doposud v zájmu výzkumů spadajících do sféry politického marketingu. 
Předmětem šetření Frenche a Smitha byly pouze dvě britské strany Konzervativní a Labouristická, o nichž má povědomí téměř $100 \%$ voličů. Co se loajality týče, ta je předmětem pravidelných sociologických šetření a autoři tak necítili potřebu se jí zabývat. Měření vnímané kvality upozadili ve prospěch vlastního subjektivního posouzení faktorů, které tuto kvalitu u každé ze stran ovlivňují. Pokud by záměrem autorů bylo představit univerzální koncept založený na všech čtyřech dimenzích, byl by tento krok problematický. Avšak jejich primární důraz na asociace a snaha o jejich hloubkové měření zvolený postup legitimizují. $\mathrm{v}$ rámci tohoto měření zohledňují fakt, že ne všechny asociace mají pro voliče stejnou váhu a hodnotu značky ovlivňují rưzným směrem (negativně/pozitivně) a intenzitou. Na základě tohoto poznatku se French se Smithem zaměrili na silu, unikátnost a preferenci asociací (French a Smith 2007). Tyto tři kategorie nebyly vybrány náhodně - vychází z konceptu Kevina Kellera, jenž jej vypracoval na počátku 90. let pro účely měření asociací s komerčními značkami. Síla odpovídá počtu asociací, které si jedinec se značkou spojí. Preference představuje negativní či pozitivní konotace se značkou a unikátnost její schopnost se odlišit - tedy počet a povaha asociací, které jsou pro danou značku jedinečné.

Co se samotného výzkumu týče, šli autoři cestou kvalitativních metod. Za respondenty byli zvoleni vysokoškolští studenti nejmenované britské university. To může být sice dostačující vzorek pro pilotní studii testující nově zkoumaný metodologický nástroj, pro širší závěry vztahující se na elektorát jako celek není ale dostatečně reprezentativní. Není ani jasné, o studenty jakého oboru se jedná - u studentů politologie a příbuzných oborů se dá očekávat vyšší míra zájmu o politiku, stejně jako odlišné množství a povaha informací o politických stranách. Taktéž jejich učení se o politických značkách je silně motivováno v porovnání se zbytkem populace. i kdyby se nejednalo o studenty specificky těchto oborů, stále by šlo o část populace, u níž je pravděpodobnější, že bude využívat více informace o politických subjektech a méně se spoléhat na kognitivní zkratky.

Autoři rozdělili množinu respondentů do dvou skupin. První byla vybídnuta ke zvolení si strany dle vlastní preference, přičemž každý účastník ke zvolené straně vypsal libovolný počet asociací, které se mu v souvislosti s ní vybavily. U druhé skupiny měření probíhalo na základě tzv. Brand Concept Maps (BCM), které umožnily autorům studie sesbírat, agregovat a vytvořit jedinečnou konsenzuální mapu, která reprezentuje asociační sít' konkrétní skupiny vztahující se ke konkrétní značce. Tento př́stup zcela odpovídá principům, na kterých je vystaven model voliče orientujícího se dle hodnoty značky. BCM odráží povahu lidské asociační sítě (HAM) a reflektuje zákonitosti vztahů mezi stimuly a uzly. Kombinací obou fází výzkumu autoři získali informaci o počtu asociací (tedy jejich síle), což se v rámci HAM projeví ve velikosti daného uzlu. Silnější propojení jednotlivých uzlů zvyšující pravděpodobnost šíření aktivace mezi nimi 
se zjistí jejich unikátností. Vedle toho byl každý respondent vybídnut k subjektivnímu posouzení povahy každé asociace - zda měla pro vnímání značky pozitivní, neutrální nebo negativní význam. Na základě jednoduchého výpočtu (X počet pozitivnich asociací - Y počet negativnich asociací) / počet asociací celkem je získána čistá valence asociací jakožto indikátor konečné hodnoty preference.

Schéma č. 1 představuje mapu asociací podporovatelů Labouristů $\mathrm{k}$ dotyčné straně. Rovněž jde o př́klad znázornění konkrétní asociační sítě k politické značce (srov. se Schématem č. 1).

\section{Schéma č. 1: Asociační sít' pro Labouristickou stranu podle Frenche a Smitha}

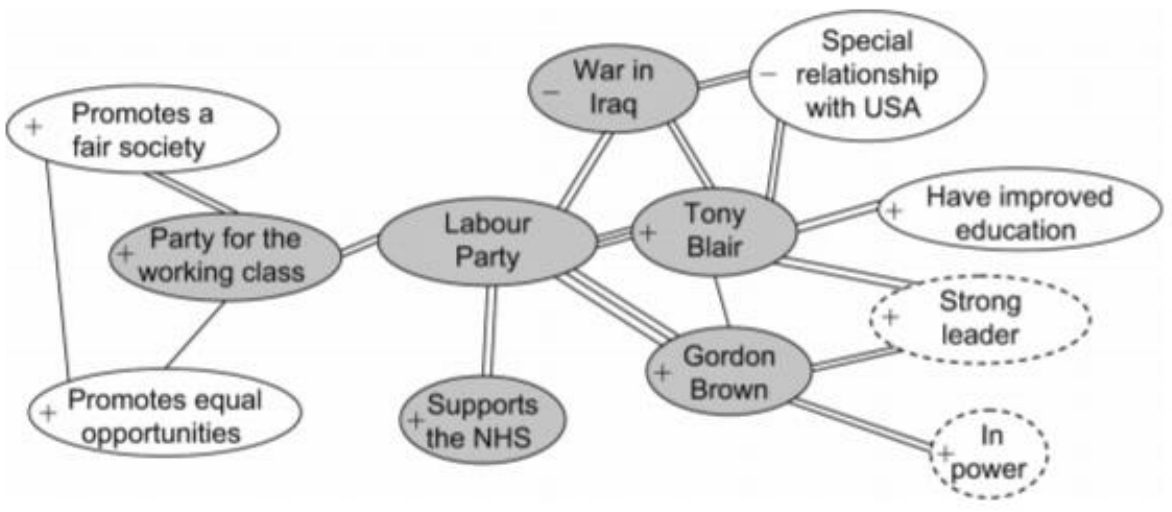

Zdroj: French a Smith (2010: 468).

Frenchovi se Smithem se díky tomuto šetření podařilo prokázat silné postavení lídra ve vnímání hodnoty politické značky, silné hodnoty značek obou sledovaných stran i obdobný počet asociací s nimi spojených. Tyto poznatky samy o sobě bez dalš́iho výzkumu mohou sloužit spíše samotným politickým stranám k vedení efektivnější kampaně, nežli politologům khlubšímu pochopení proměnných ovlivňující volební chování. Vybereme-li odlišný vzorek, např. nerozhodnuté voliče nebo voliče s nižší úrovní vzdělání a zájmem o politiku a provedeme stejné šetření na identickém vzorku ve více vlnách před předvolební kampaní, v jejím průběhu a po jejím konci, získáme tak důležitou informaci o vzájemném ovlivnění hodnoty politické značky, předvolební kampaně a intence jít k volbám.

Stejný metodologický př́stup jako French se Smithem zvolili autoři studie zaměřující se na hodnotu politické značky v Irsku. Mac Donald, Sherlock a Hogan (2014) se pokusili odkrýt kognitivní struktury voličů vytvořené kolem stran Fianna Fáil, Fine Gael, Sinn Fein, The Labour Party a sílu, unikátnost a preferenci asociací. Postup byl totožný - respondenty i zde tvořili studenti vysoké školy, přičemž přidanou hodnotu lze pozorovat $\mathrm{v}$ odlišném politickém prostředí (např. 
absence běžných štěpících linií, odlišný volební systém apod.), ve kterém byl výzkum proveden. Obdobně jako u Smitha a Frenche, i zde výsledky potvrdily odlišné hodnoty značek stran; stejně tak ale i v tomto př́padě naráží výzkum na stejné limity (výběr vzorku, absence zasazení závěrů do širšího teoretického rámce). v obou prrípadech pak chybí závěry vztahující se k možným dopadům na volební chování, přičemž právě odlišné politické prostředí vybízí ke komplexnějším analýzám (nap̌r. komparace hodnoty politické značky irské i britské Labour party).

\section{b. Aleksiejevas: multidimenzionální model hodnoty politické značky}

Zajímavý pokus o měření hodnoty politické značky, které by v sobě zahrnovalo vícero dimenzí, představil Mantas Aleksiejevas. Na základě vytyčení rozdílů mezi politickou a komerční značkou určil několik měřitelných indikátorů, které rozdělil do devíti kategorií, respektive dimenzí (viz Schéma č. 2). Většina z nich vychází z předchozích prací Aaker, Kellera, Frenche a Smitha a dalších., nicméně některé kategorie Aleksiejevas přidává zcela nově a u těch je potřeba se krátce pozastavit. (Ještě předtím je potřeba zmínit, že autor model doposud nijak empiricky netestoval a jeho sestavení je postaveno na výsledcích dotazníkového šetření mezi odborníky na politický marketing a branding).

Schéma č. 2: Multidimenzionální přístup k měření hodnoty značky dle Aleksiejevase

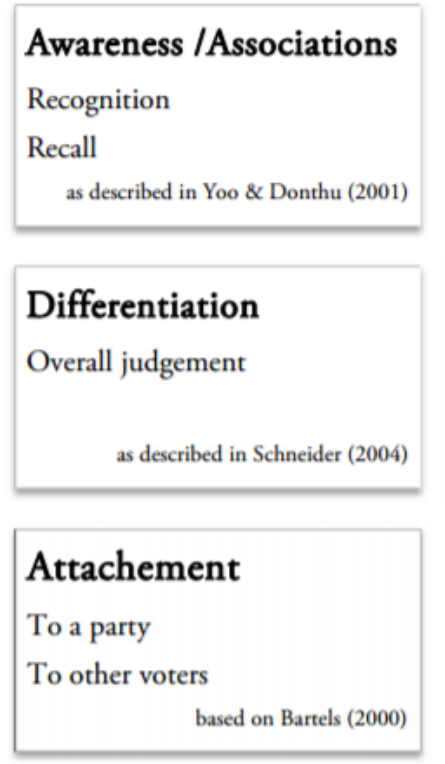

Zdroj: Aleksiejevas (2012: 14).
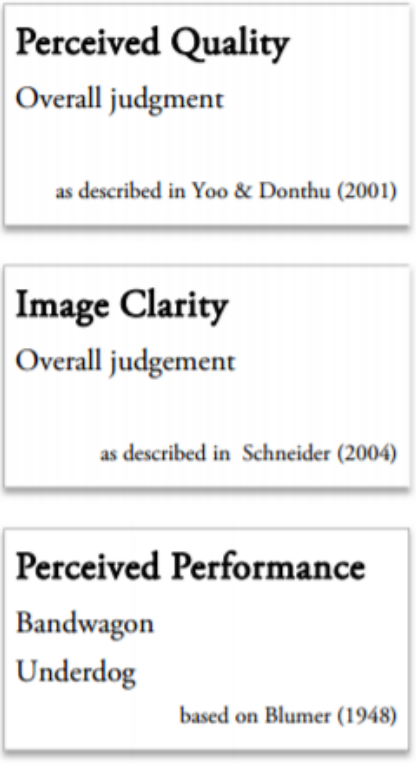

\section{Loyalty \\ Attitudinal \\ Behavioural \\ as described in Yoo \& Donthu (2001)}

\section{Trust}

Fulfilled Expectations

Fulfilled Promises

based on Lock \& Harris (1996)

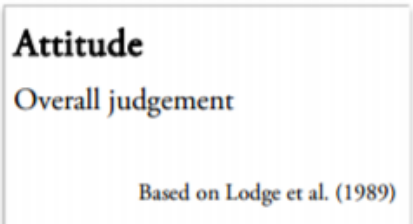


Kategorie brand attachment (připoutání ke značce) je založena na jednom důležitém aspektu volebního chování - bylo dokázáno, že emocionální napojení na určitou skupinu lidí, tedy jakýsi smysl pro komunitu, je silně spojeno s volební účastí. Předchozí práce věnující se problematice politických značek tuto skutečnost nijak nereflektovaly. Aleksiejevas připoutání ke značce pojímá jako sílu spojení mezi značkou a jedincem, což do jisté míry souvisí s klasickým konceptem stranické identifikace. Existence této dimenze je tak vystavěna na jasných teoretických základech a autorovi se ji daří věcně vyargumentovat. To samé však nelze tvrdit o dalších dodaných dimenzích. Problematické je dle mého posouzení dimenze Attitude (prrístup). v rámci její charakteristiky autor píše, že: ,je nutné mít dimenzi, která zhodnocuje celkový dojem“ (Aleksiejevas n.d.: 12) Celkový dojem je však souhrnem veškerých asociací. Proč tedy tvořit zcela novou dimenzi? Obdobně problematická je i dimenze Perceived Performance, která chce do měření hodnoty politické značky zahrnout i vliv veřejného mínění, nap̌r. vliv tzv. bandwagon $^{12}$ a underdog ${ }^{13}$ efektů. Jako by se autor snažil do svého multidimenzionálního modelu zahrnout veškeré faktory ovlivňující volební chování, bohužel bez dostatečného teoretického zázemí.

Avšak z mého pohledu nejspornější částí Aleksiejevasova modelu je jeho spojení sledovaných kategorií Awareness (povědomí o značce) a Associations (asociace se značkou). To, zda jedinec má či nemá povědomí o značce, je prvotní fází měření hodnoty značky následovanou měřením asociací. Nicméně $\mathrm{k}$ tomuto měření Aleksiejevas přistupuje kategoricky - zda jsou asociace přítomny či nikoliv. Nicméně pro model voliče orientovaného na značku a tudíž nový potencionální teoretický koncept vysvětlující volební chování je podstatná povaha a síla asociací, nejen jejich přítomnost a počet. Předkládaný multidimenzionální model jde sice do šíre, ale nikoliv do hloubky problému. i přesto ale nabízí zajímavé dodatky ke stávajícím postupům a jedná se o vcelku podařenou syntézu dosavadních př́istupů $\mathrm{k}$ měření hodnoty politické značky.

\section{c. Pich a Dean: kvalitativní projektivní techniky}

Britští političtí vědci Christopher Pich a Dianne Dean zvolili pro výzkum asociací se značkou jedinečný př́stup. Sběr dat byl zajištěn skrze tzv. projektivní techniky, které umožňují projekci hlubokých, vědomých i nevědomých pocitů a asociací do různých stimulů (Pich a Dean 2015). Jsou vhodné v př́padech, kdy chceme konkrétní problém pochopit více do hloubky a rezignujeme na zevšeobecňující závěry. Vzhledem k uvedeným vlastnostem se tyto techniky hodí do těch oblastí výzkumu, které nejsou tolik probádané. Tím je i politický branding.

\footnotetext{
12 Tendence většinou nerozhodnutých voličů přidat se $\mathrm{k}$ volbě strany, která má největši šanci zvítězit.

13 Situace, kdy se voliči přikloní na stranu toho, kdo v průzkumech zaostává.
} 
Projektivní techniky $\mathrm{v}$ podobě zvolené Pichem a Deanem jsou relativně složité a kladou na výzkumníky vysoké nároky. Ve svém př́spěvku popisují několik fází, které prostupovaly focus groups s vybranými respondenty. Jednalo se o mladé lidi ve věku 18-24 let, kteři patři mezi nejodcizenější část britského elektorátu a zároveň mezi nejmenší voličskou skupinu Konzervativní strany, tedy toho subjektu, který byl předmětem zájmu výzkumníků. Důkladný popis všech fází není pro tento text podstatný. Důležitá je možnost spojení této praxe s teorií, tedy konkrétně s modelem voliče orientovaným na politickou značku. $\mathrm{v}$ průběhu skupinových rozhovorů se projevila schopnost projekčních technik vyvolat u účastníků skryté pocity a asociace s politickou stranou - dokonce i u těch respondentů, kteří se na počátku skupinových diskusí označili za osoby bez zájmu o politiku a bez jakýchkoliv politických znalostí (Pich a Dean 2015). Nicméně s těmito výstupy autoři nijak dále nepracují a pouze se spokojují s představením měřícího nástroje. Opět zde tak chybí zasazení do vhodného teoretického rámce; př́spěvek lze proto řadit $\mathrm{k}$ těm pracím, jejichž výstupy poslouží spíše praktikům politického marketingu. Vliv skrytých asociací na voliče a tvorbu jejich rozhodnutí je dosud naprosto neprobádanou oblast politologie a je zde tudíž šance, že se podaří získat zcela nové informace o podmínkách vytváření volebního rozhodnutí a faktorů, které na něj působí. Výše popsané výsledky u participantů odcizených od politiky můžeme vztáhnout $\mathrm{k}$ modelu voliče orientovaného na politickou značku. Ten pracuje s premisou, že lidé nejsou motivováni k poznávání a učení se informací o politických značkách. Nabízí se tak možnost intenzivnějšího zaměření na tyto respondenty s cílem zjistit, do jaké míry je jejich skryté asociace ovlivňují ve volebním chování ve srovnání s ostatními proměnnými, vycházejícími z klasických teorií volebního chování (socioekonomický status, vzdělání, síla stranické identifikace apod). Př́kladem proměnné vycházející z klasické teorie a uzpůsobené pro politický branding je výše zmiňovaná Aleksiejevasova kategorie Brand attachment. Pich a Dean však s takto podrobnými profily respondentů nepracují a ochuzují se tak o další možnou úroveň bádání.

\section{d. Almohammad: hodnota politické značky založená na emocích}

Dosavadní zde uvedené př́stupy $\mathrm{k}$ měření hodnoty politické značky sice pracují s pamět'ovou asociační sítí, ovšem „očištěnou“ od emocí. Jinak řečeno sice se dozvíme, zda jsou asociace negativní nebo pozitivní povahy, ale nezískáme žádnou informaci o skrytých emocích. v posledních letech se přitom objevují studie, které uznávají silný vliv emocí v politickém chování (a ve volebním obzvláště).$^{14} \mathrm{I} z$ toho důvodu je poslední práce prezentovaná $\mathrm{v}$ této přehledové studii vystavěna na emocích jakožto pevné součásti hodnoty politické značky.

Asaad Almohammad (2014) teoreticky vychází z teorie př́ícinné souvislosti politických emocí, která popisuje proces vyvolání politických emocí jakožto

14 Viz např. Pagano a Huo (2007) nebo Weber (2007). 
výsledek dvou kognitivních funkcí - asociační a propoziční. Zatímco prvně zmiňovaná funkce je automatickým procesem, v jehož rámci je nalezený objekt (obrázek, logo, osoba) poznačen, zda patří do pozitivní nebo negativní kategorie, propoziční funkce odráží vědomé hodnotící tendence, které mají jednotlivci tendenci vykonávat, aby mohli přiřadit objektu emocionální nebo smyslový význam. Základem automatické aktivace je rozšiřování aktivace skrze asociační sít' (zahrnující uzly), prričemž se celý tento proces projeví v rámci tzv. implicitni emoce. To zjednodušeně řečeno znamená první vnímaný emoční stav, který se vyskytuje automaticky s malým nebo žádným vědomým př́stupem ze strany jedince. Druhý vnímaný stav je následně výsledkem už vědomého zpracování informací jednotlivcem; z něj vychází tzv. explicitni emoce. Almohammad pracuje s daným dělením emocí ve svém měření hodnoty politické značky a jako takovou ji definuje jako rozdíl účinků emocí značky na volební rozhodnutí jedince. Cíleně tak zasazuje měření hodnoty značky do širšího rámce zkoumajícího vlivy na volební rozhodování. Dle jeho názoru silná pozitivní hodnota politické značky založená na emocích může vést voliče k potlačení negativní implicitní emoce a dokonce povzbudit pozitivní explicitní emoce (při zpracování informací o objektu-značce dochází k posílení těch pozitivně vyznívajících). Konceptualizace vztahu mezi implicitními a explicitními emocemi však popisuje rovnocenné postavení obou druhů emocí v jejich explanatorní funkci - tedy obě emoce mají stejnou sílu při vysvětlení volebního chování (Almohammad 2014). Avšak při pohledu na specifickou skupinu voličů vyznačující se nezájmem o politiku a nízkou úrovní vzdělání by se dala očekávat výraznější role implicitní emoce ve volebním chování.

Měření emocí je z metodologického úhlu pohledu vždy složitější, nežli měření asociací. Odpovídá tomu široký výběr kvantitativních technik, které Almohammad využil. První fáze spočívala $\mathrm{v}$ panelovém šetření s náhodným výběrem ( $v$ rámci Americké národní volební studie, ANES). Vzhledem k rozsáhlosti průzkumu a následné možnosti generalizace výsledků nebyly zjišt'ovány nahodilé emoce, nýbrž byl respondentům $\mathrm{k}$ dispozici výčet čtyř předem vybraných: zlost, strach, naděje a hrdost. Za pomoci Likertovy škály lidé prriřazovali uvedené emoce jak ke dvěma hlavním stranám (Demokraté a Republikáni), tak i k prezidentským kandidátům. Posléze bylo přistoupeno k relativně složitým statistickým metodám zpracování kvantitativních dat (faktorová analýza, měření adekvátnosti výběru, logistická regrese). Díky tomu mohl autor získat informace o prediktivní povaze hodnoty politické značky založené na emocích. Nejenže byly výsledky statisticky významné, ale hodnota politické značky založená na emocích vysvětlila až $74 \%$ rozptylu ve volebních rozhodnutích. Almohammadovi se podařilo taktéž prokázat, že konceptualizace vztahu mezi implicitní a explicitní emocí není správná, jelikož implicitní emoce se ukázala jako nejsilnější prediktor volebního chování (voliči, kteří se rozhodovali nevědomě, by v rámci výzkumu 1,4krát častěji volili Baracka Obamu). Implicitní 
dimenze tak prokázala silnou prediktivní sílu při zachycení behaviourálních vlivů hodnoty politické značky vystavěné na emocích. Na druhou stranu mezi explicitní emocí značky a hlasováním byl odkryt velmi slabý vztah (Almohammad 2014). Zde se tak otevírá prostor pro další výzkum, který by osvětlil, jaký druh emocí a jakým způsobem působí na odlišné segmenty elektorátu.

\section{Závěr}

Politický branding je postaven na tezi označující jedince za nemotivovaného voliče, který z různých důvodů nemá potřebu aktivně vyhledávat informace o politických stranách a kandidátech. Ohlédneme-li od jiných faktorů vysvětlujících volební chování (racionální volba, třídní volba...), nabízí se i jiná alternativní vysvětlení. voblasti politického brandingu je jím model voliče orientujícího se na hodnotu politické značky. Je zcela na místě zdůraznit, že se jedná o teoretický koncept, který nebyl doposud konkluzivně empiricky ověren a spíše nežli funkční model představuje soubor tezí o spojení hodnoty politické značky a volebního chování. To však neodradilo řadu vědců od toho, aby se ve svých pracích zaměřili na měrení zmiňované hodnoty. Práce Smitha, Frenche, Aleksiejevase a Deana a Pinche sice znamenají pokroky v konceptualizaci hodnoty značky, ale chybí jim jakékoliv propojení s volebním chováním, tedy ústředním bodem zájmu klasické politologie. Informace o tom, jak hodnotí danou stranu voliči, sama o sobě slouží spíše politickým marketérům a volebním manažerům, kteří mohou na základě nich poupravit volební strategie. Menší přidanou hodnotu však budou mít pro politology, kteři se snaží nalézt a pochopit proměnné, jež mohou mít vliv na to, jak si voliči utváŕi své preference o politických stranách. Politický branding tak i zde naráží na limity, se kterými se potýká i politický marketing - nedostatečné teoretické zázemí a napojení na „klasickou“ politologii.

Zřjejmě nejkvalifikovanější př́stup $\mathrm{k}$ měření hodnoty značky, využívající široké spektrum metod a vystavěný na jasném teoretickém základě, nabídl Assad Almohammad, který se pokusil odkrýt skryté emoce prokazatelně ovlivňující volební chování. Jeho text není pouhým představením modelu měřícího hodnotu značky, ale daří se mu propojit oblast brandingu s politologickými výzkumy, když prokazuje vztah mezi hodnotou značky a volebním chováním. Dostatečně tak zodpovídá otázku, zda je politický branding schopen nabídnout nové teoretické koncepty i nástroje pro pochopení volebního chování. Pokud se nové výzkumy neomezí na informování o odlišných asociacích sledovaných politických stran v konkrétní zemi (jako u Smitha a Frenche nebo Pinche a Dean), ale jejich záměrem bude verifikace hypotéz deklarujících existenci a následně i upřesňujících podobu vztahu mezi hodnotou značky strany/lídra a volebním chováním, získá tak politický branding možnost postavit se vedle klasických teorií volebního chování a prrispět do letité a stále živé diskuze o tom, proč a jak občané volí. Předkládaný text není sice vyčerpávajícím přehledem všech prací vztahujících se 
$\mathrm{k}$ politickému brandingu, avšak nabídl čtenáři výběr možných prústupů k měření hodnotě značek, které mohou sloužit jako základ pro obdobné výzkumy i v české politologii. Ty by se však měly z empirického hlediska vydat dále, než míŕi tento text, a pokusit se sesbírat data takové povahy, jež by umožnila hlubší pochopení fenoménu značek $v$ politice.

\section{Literatura a prameny ${ }^{15}$}

Adolphsen, Manuel (2009): „Branding in Election Campaigns. Just a Buzzword or a New Quality of Political Communication?" Disertační práce, on-line (http://www.lse.ac.uk/media@lse/research/mediaWorkingPapers/MScDissertationSer ies/Past/Adolphsen_final.pdf)

Aleksiejevas, Mantas (2012): The V alue of Political Brand: Introducing a Measure of Political Brand Equity. University of Amsterdam. MSc. Thesis, University of Amsterdam, on-line (http://arno.uva.nl/cgi/arno/show.cgi?fid=357330).

Almohammad, Assad H. 2014. „The Conceptualisation and Operationalisation of Emotion-based Political Brand Equity." Journal of Marketing Management 2(2): 165-194.

Bartle, John a Dylan Griffiths (2002): „Social Psychological Economic and Marketing Models of Voting Behaviour Compared." In: Nicholas J. O’Shaughnessy a Stephan C. M. Henneberg (eds), The Idea of Political Marketing. London: Preager, 19-38.

Beck, Ulrich (1992): Risk Society. Towards a New modernity. London: Sage.

Blumler, Jay a Dennis Kavanagh (1999): „The Third Age of Political Communication: Influences and Features.“ Political Communication 16(3): 211-213. DOI: 10.1080/ 105846099198596

Campbell, Angus, Philip E. Converse, Warren E. Miller a Donald E. Stokes (1960): The American voter. New York: Wiley \& Sons.

Coleman John J. (1996): „Party Organizational Strenght and Public Support for Parties.“ American Journal of Political Science 40(3): 806-807.

Costa, Jordana a Anna Corte-Real (2013): „The Impact of Ideology in the Voting Decision Making Process." Universidade Catolica Portuguesa, on-line (https://ideas.repec.org/p/cap/mpaper/012013.html)

Dalton, Russel J. a Martin P. Wattenberg (2000): Parties without Partisans. Political Change in Advanced Industrial Democracies. New York: Oxford University Press

Davis, Aeron (2010): Political Communication and Social Theory. New York. Routledge.

de Chernatony, L. (2009): Značka: od vize k vy šsim ziskiom. Computer Press.

Dostál, V. (2010): „Nerozhodnutých je dosud asi pětina voličü.“ Deník Referendum, 1. 10. 2013, online (http://denikreferendum.cz/clanek/16512-nerozhodnutych-je-dosud-asipetina-volicu

Downer, Lorann. (2013): „Political branding in Australia. a conceptual model.“ Př́spěvek př̀ednesený na 63. výroční konferenci Asociace pro politická studia. Cardiff, březen 2013, on-line (https://www.psa.ac.uk/sites/default/files/2848_633.pdf)

Downs, Anthony (1957): „An Economic Theory of Political Action in a Democracy.“ Journal of Political Economy 65(2): 142-145. DOI: 10.1086/257897

15 Elektronické zdroje ověřeny k 11. 10. 2017. 
Eghbalian, Stefan a Stephan C. M. Henneberg (2002): „Kirchheimer's Catch-all Party: a reinterpretation in marketing terms." In: Nicholas J. O’Shaughnessy a Stephan C. M. Henneberg (eds.), The Idea of Political Marketing. London: Preager, 67-91.

Fawcett, Paul a David Marsh (2011): „Branding, politics and democracy.“ Policy Studies 32(5): 515-530.

French, Alan a Gareth Smith (2010): „Measuring political brand equity: a consumer oriented approach." European Journal of Marketing 44(3-4): 460-477. DOI: 10.1108/03090561011020534

Harris, Phil, a Andrew Lock (1996): „Political marketing - vive la différence!“ European Journal of Marketing 30 (10-11): 14-24. DOI: 10.1108/03090569610149764

Healey, Mathew (2009): Co je branding? Praha: Slovart.

Henneberg, Stephan C. M. (2002): „Understanding Political Marketing.“ In: Nicholas J. O’Shaughnessy a Stephan C. M. Henneberg (eds.), The Idea of Political Marketing. London: Preager, 93-170

Henneberg, Stephan C. M. (2006): „Strategic postures of political marketing: an exploratory operationalization." Journal of Public Affairs 6(1): 15-30. DOI: 10.1002/pa.39

Hlidacipes.org (2017): „Proč je Babiš tak úspěšný? Tajné triky nejoblíbenějšího politika.“ HlídacîPes, 30. 10. 2017, on-line (http://hlidacipes.org/tajne-triky-nejoblibenejsihopolitika-aneb-proc-je-babis-tak-uspesny/).

Holland, DK. (2006): Branding for Nonprofits. Allworth Press.

Holt, Douglas B. (2006): „Toward a Sociology of Branding. " Journal of Consumer Culture 6(3), 299-302. DOI: 10.1177/1469540506068680

Keller, Kevin L. (2002): „Branding and Brand Equity.” In: Bart Weitz a Robin Wensley (eds.), Handbook of Marketing. London: Sage, 151-178

Keller, Kevin L. (2007): Strategické rízeni značky. Praha: Grada.

Kirchheimer, Otto (1966): „The Transformation of Western European Party Systems.“ In: Joseph LaPalombara a Myron Winer (eds), Political Parties and Political Development. Princeton: Princeton University Press, 171-200.

Kornberger Martin (2006): Brand Society: How Brands Transform Management and Lifestyle. Cambridge: Cambridge University Press.

Krouwel, André (2003): „Otto Kirchheimer and the Catch - All Party.“ West European Politics 26(2): 23-40. DOI: 10.1080/01402380512331341091

Kudrnáč, Aleš (2015): „Poznají Češi loga politických stran a záleží na tom?“ In: Pat Lyons a Rita Kindlerová (eds.), 47 odstínu české společnosti. Praha: Sociologický ústav AV ČR, 3742.

Lees-Marshment Jennifer (2001): Political marketing and British political parties: The party's just begun. Manchester: Manchester University Press.

Lidovky.cz (2017): „Sobotka končí v čele ČSSD, nahradí jej Chovanec. Volebním lídrem bude Zaorálek." Lidové noviny, 14. 6. 2017, on-line (http://www.lidovky.cz/sobotkaopusti-funkci-predsedy-cssd-nahradi-jej-chovanec-pet-/zprávy-domov-aspx?c=A170614 _192635_ln_domov_ELE).

McDonald Evan A. a Roger Sherlock a John Hogan (2014): „Measuring Political Brand Equity in Ireland." Irish Political Studies 30(1): 98-120. DOI: 10.1080/ 07907184.2014.942644 
Nedungadi, Prakash a J. Wesley Hutchinson (1985): „The Prototypicality of Brands: Relationships With Brand Awareness, Preference and Usage." Advances in Consumer Research 12: 498-503.

Needham, Catherine (2006): „Brands and political loyalty.” Journal of Brand Management 13(3): 178-187. DOI: 10.1057/palgrave.bm.2540260

Newman, Bruce I. (1993): The Marketing of the President: Political Marketing as Campaign Strategy. London: SAGE Publications.

Nielsen, Sigge W. a Martin V. Larsen (2013): „Party brands and voting.“ Electoral Studies 33: 153-65. DOI: 10.1016/j.electstud.2013.08.001

Pagano, Sabrina J. a Yuen J. Huo (2007): „The Role of Moral Emotions in Predicting Support for Political Actions in Post-War Iraq." Political Psychology 28(2): 227-255. DOI: 10.1111/j.1467-9221.2007.00563.x

Peng, Norman a Chris Hackley (2009): „Are voters, consumers? a qualitative exploration of the voter-consumer analogy in political marketing“ Qualitative Market Research: An International Journal 12(2): 171-186. DOI: 10.1108/13522750910948770

Pich, Christopher a Dianne Dean (2015): „Qualitative projective techniques in political brand image research from the perspective of young adults." Qualitative Market Research: An International Journal 18(1): 115-144. DOI: 10.1108/QMR-12-2012-0058

Scammel Margaret (1999): „Political marketing: lessons for political science." Political Studies 47(4): 718-739. DOI: 10.1111/1467-9248.00228

Schneider, Helmut (2004): „Branding in Politics - Manifestations, Relevance and IdentityOriented Management." Journal of Political Marketing 3(3): 41-56. DOI: 10.1300/ J199v03n03_03

Smith, Gareth (2009): „Conceptualizing and Testing Brand Personality in British Politics." Journal of Political Marketing 8(3): 209-232. DOI: 10.1080/15377850903044858

Smith, Gareth a Alan French (2009): „The political brand: a consumer perspective.“ Marketing Theory 9(2): 209-226. DOI: 10.1177/1470593109103068

Teichert Thorsten A. a Katja Schontag (2010): „Exploring Consumer Knowledge Structures Using Associative Network Analysis.“ Psychology \& Marketing 27(4), 369-398. DOI: $10.1002 /$ mar.20332

Weber, Christopher R. (2008): The emotional campaign: How emotions influence political behaviour and judgment. Dizertační práce, State University of New York.

Winchester, Tiffany, John Hall a Wayne Binney (2016): „Conceptualising Usage in Voter Behaviour for Political Marketing: An Application of Consumer Behaviour." Journal of Political Marketing 15(2-3): 259-284. DOI: 10.1080/15377857.2016.1151126

\section{The Theoretical Foundations of Political Branding: Introducing the Brand Voter Model and its Methodological Anchoring}

\section{SUMMARY}

Political branding is, like the broader discipline of political marketing, criticized for lack of theory at the expense of empiricism. It is, supposedly, more about cases of practice, 
instructions for politicians and political parties about how to convince voters. If we want to incorporate branding not only into political practice but also into science (political science in particular), it is necessary to synthesize existing conceptual frameworks that are suitable for further theoretical development and critically evaluate their explanatory potential in relation to electoral behaviour. This text works with a specific area of political branding research the, so-called, model of brand orientated voter based on the concept of the human association network (HAM). It describes how the information nodes function in human memory. For political science and political branding in particular, HAM is used to explain the party's / candidate's electoral information processing, and to identify parties in a moment of confrontation with political news. This learning is not motivated, and the association with the political brand stored in the voter's memory acts as an intuitive tool that can influence him/her in the electoral decision.

Political branding can thus, from a theoretical point of view, help the political scientist explain the electoral behaviour of a society that is now in a period of the second modernity where the voter choice is not entirely determined by classical variables such as social or ideological anchor, but his/her behaviour is influenced by other factors such as emotions or relationship with the brand. However, the research question of the presented text is whether the current level of research in the field of political branding is sufficiently equipped with a conceptual frameworks and methodological tools to clearly link the two concepts - value of the brand and voting behaviour and whether political branding is at a stage when it is able to verify a hypotheses about linking electoral behaviour and political brand values.

After the breakthrough work of Smith and French, who introduced the possibility of measuring the value of a political brand, they were followed by similarly focused researched surveys, sometimes modified only minimally (e.g. McDonald, Sherlock and Hogan). Smith and French were able to get valuable data through focus groups with high school students, which then underwent analyses through qualitative methods. They have demonstrated the strong position of the leader in perceiving the value of the political brand and the strong brand value of the surveyed parties. However, the results are not linked to electoral behaviour, which, moreover, was not the goal of Smith and French. Still, in my opinion, this is the cornerstone of other relevant research on political branding and therefore I am including it in this critical study.

British political scientists Ch. Pich and D. Dean chose a unique approach to the research of the brand associations. Data collection was secured through so-called projective techniques that allow the projection of deep, conscious and unconscious feelings and associations into various stimuli. During group interviews the ability of these design techniques to evoke hidden feelings and associations with a political party was revealed, even in respondents who were identified as those without an interest in politics and without any political knowledge at the beginning of the research. Nevertheless the authors do not work anymore with these outputs and are only satisfied with the presentation of the measuring instrument. Again, there is no fitting into a suitable theoretical framework, and the contribution can be grouped to those works whose outputs serve political marketing practitioners. The influence of hidden associations on voters and their decision-making is still an unprecedented field of political science, so there is a chance that we will be able to get completely new information about the conditions of the election process and the factors that affect it. For this reason, it is also 
an important contribution to the debate on the possible effects of political brands on electoral decision-making.

Another attempt to measure the value of a political brand is a multidimensional model of measuring political brands presented by Mantas Aleksiejevas and based on the French and Smith's study. Aleksiejevas adds other dimensions to political brands such as perceived quality, loyalty, differentiation, image, trust, attachment, perceived performance and attitude. In the text, I emphasize the controversial dimensions and subject them to criticism. Aleksiejevas's model is wider than previous authors, but at the expense of detailed knowledge. Unlike Smith and French, however, there is an added value in engaging emotions, in the perception of brand value. Aleksiejevas study is a sort of thought bridge between French and Smith and another elaborate author A.H. Almohammad. The last mentioned author is farthest in the research of the value of the political brand and its possible influence on electoral behaviour. He works with HAM, but unlike previous authors, he tries to understand not only the power (number) and direction of the associations, but also the hidden emotions in the background. Almohammad relies heavily on the causal link of political emotions that describe the way in which political emotions are evoked. The value of a political brand is defined as the effect of the implicit and explicit emotions of the brand on the voting decision of the individual. Thus, it measures the value of the brand in a wider framework of investigating the influence on electoral decision making. In his view, the strong positive value of emotion-based political signals can lead voters to suppress negative emotional impulses (i.e., the first perceived emotional state that comes after meeting with the brand's attribute) and even to encourage positive explicit emotions (when processing information about the subject - those positive ones). Thus, the whole text is not just a presentation of the brand's benchmarking model, but it succeeds in linking the branding area with political science by proving the relationship between brand value and electoral behaviour. It adequately answers the question of whether political branding is able to offer new theoretical concepts and methodological tools for understanding electoral behaviour.

If the new research is not limited only to informing about different associations of monitored political parties in a particular country (see Smith and French or Dean and Pinch), but their intention is to verify the hypotheses declaring existence and subsequently specifying the relationship between party / leader brand value and voting intentions, it will give political branding the ability to stand up to classical theories of electoral behaviour and to contribute to an age-old and still lively discussion of why and how citizens vote. Although the present text is not an exhaustive overview of all political branding work, it has offered its readers a choice of possible approaches to measuring the value of brands that can serve as a basis for similar research in Czech political science as well. However, this new research should, from an empirical point of view, go further than this work and gather data that would allow a deeper understanding of the brand phenomenon in politics. 